\title{
Lumen
}

Selected Proceedings from the Canadian Society for Eighteenth-Century Studies

\section{The Family in the Novels of Sarah Harriet Burney}

\section{Lorna J. Clark}

Volume 20, 2001

URI : https://id.erudit.org/iderudit/1012303ar

DOI : https://doi.org/10.7202/1012303ar

Aller au sommaire du numéro

Éditeur(s)

Canadian Society for Eighteenth-Century Studies / Société canadienne d'étude du dix-huitième siècle

ISSN

1209-3696 (imprimé)

1927-8284 (numérique)

Découvrir la revue

Citer cet article

Clark, L. J. (2001). The Family in the Novels of Sarah Harriet Burney. Lumen, 20 , 71-81. https://doi.org/10.7202/1012303ar

Copyright (c) Canadian Society for Eighteenth-Century Studies / Sociéte canadienne d'étude du dix-huitième siècle, 2001
Ce document est protégé par la loi sur le droit d'auteur. L'utilisation des services d'Érudit (y compris la reproduction) est assujettie à sa politique d'utilisation que vous pouvez consulter en ligne.

https://apropos.erudit.org/fr/usagers/politique-dutilisation/ 


\section{The Family in the Novels of Sarah Harriet Burney}

The mere ceremony of assembling in the same room, and calling each other mother and daughter, cousin and brother, effects but little. Ease and intimacy are so far from being inseparably attached to nearness of kindred, that in the whole circle of creation, nothing can surpass the heaviness and restraint which is often seen...pervading, 'in clouded majesty,' a family party. ${ }^{1}$

This passage, quoted from a best-selling novel by Sarah Harriet Burney (1772-1844), may be cited as indicative of an attitude prevalent in her work. The family, whose ideology is central to the period, ${ }^{2}$ as well as to the genre in which she writes, is a central concern of her fiction. It functions both as a structuring principle and an omnipresent entity encompassing the action. Ideally a source of nurturing and strength (offering a 'safe place in the wider world'), ${ }^{3}$ this ideal is represented primarily by means of contrast, negation and absence. More often, the family is the site of oppression and constraint; it plays a coercive rather than supportive role in that all-important area of individual choice choosing a mate. As the smallest unit of society, it carries the burden of social expectations and transfers their crushing weight onto the individual. Women as well as men are subjected to victimization, persecution, and the repression of desire.

The creation of new families and the re-alignment and merging of the old is the end point of her fiction. Most of Burney's work (three novels and four tales published between 1796 and 1839) is written in the genre of 'domestic novel of manners' focusing on the heroine's 'coming-out,' the moment of her introduction to the wider world. The action of the novel follows 'the process of initiation, and education ${ }^{4}$ through a period of courtship in which the protagonist's progress to maturity is crystallized in the concluding marriage. The plot is structured as a quest - for self-identity and acceptance into patriarchal society.

The heroine is solitary for much of the novel, haunted by 'the consciousness, that she alone was an interdicted, a rejected being amidst so many connections. ${ }^{5}$ Her isolation is signaled by the fact that she is an orphan. Most of Burney's heroines share this friendless state, having lost 
at least one parent. There is but one exception, The Shipwreck (1816), in which the protagonist starts out with both; however, her position soon becomes isolated in the extreme. Sailing to meet her father in India, she is marooned on a desert island with her mother, who dies in the course of the action. Her grief at her bereavement in a literal desert is tremendous: 'Many have lost a parent, but who ever experienced the aggravations of such a loss which I am sentenced to suffer?' ${ }^{6}$

This moment of complete abandonment in the face of an uncaring universe is echoed in several of her works. The heroine confronts the sheer terror of loneliness and the sense of her own insignificance in a manner similar to that of Agnes in The Renunciation:

Once more she saw herself a lone being in creation;...she was without kindred - without a home - without even a name she could legally appropriate - ....It was a perspective that at once filled her with grief, terror, and self-compassion, and her tears long continued to flow with undiminished bitterness. ${ }^{7}$

This moment occurs at the nadir of her fortunes before she commences her trajectory upwards in quest of kindred - which, even more than a mate, is the focus of her desire.

Isolation is repeated as a motif in minor characters - no fewer than three in Geraldine Fauconberg (1808), for instance. Of these, the wealthy widow Mrs. Neville, 'young, beautiful, opulent,' is yet most pitiable. ${ }^{8}$ Though she possesses every worldly advantage, her dearth of connections is fatal to her happiness: rootless, restless and dissatisfied, she pursues a reckless career which proceeds from flirtation to the brink of loss of reputation. Her wealth and independence give her freedom but too much freedom endangers the female character, whose safety lies in being firmly rooted in family connections. The heroine's purpose is to find and establish these relations.

Of course, the heroine as orphan can be seen as a convention in 'feminocentric novels of social initiation.' The 'advantage of this disadvantage for the novel,' according to Nancy Miller in The Heroine's Text, is obvious. If the basic plot of the novel is the quest for self-identity, or, as she puts it, the 'insertion of the individual into the sociolect,' then 'the female orphan offers the 18th-century novelist still more built-in narrational fringe benefits because social insecurity is compounded by sexual vulnerability; the orphan-heroine constitutes a predictive series of blanks to be filled in. ${ }^{9}$ She argues that in novels like Defoe's Moll Flanders, the heroine's fundamental need, far greater than her desire for a lover, is to discover a family, to surround herself with friends and relations, to confirm a sense of belonging and construct a social identity. 
In Clarentine (1796), Burney's first novel, the heroine is truly rootless. Her progress is measured against a shifting series of family groups, to none of which she is deeply attached. Nor are they able to offer her protection from the malevolence to which she is exposed. In a pattern of duplication (another characteristic motif), Clarentine in effect becomes a 'serial' orphan: after losing both parents in infancy, she is relinquished by the aunt who befriended her and brought up by an uncle who subsequently dies. Her refuge with her uncle's widow is closed to her through the enmity of an overbearing matriarch. She is briefly domesticated with a maternal aunt, who is yet unable to protect her from an importunate suitor. She then enters the household of an elderly guardian, who appears to resemble Mr. Villars of Evelina as a venerable mentor figure, but proves curiously ineffectual. Finally, she travels to Bath with a recent acquaintance, under whose auspices she reaches an understanding with the hero and an end to her travails.

A sense of persecution dogs Clarentine through all these changes, as she is exposed to malicious aspersions and manipulated by an evil genius who is 'less a woman than a fiend!' ${ }^{10}$ The novel is unusual in that the figures of authority are all female. The absence of powerful male figures may explain the novel's moral anarchy, the fact that hero and heroine are defenseless against the evils that surround them, and are rescued by events beyond their control. The family, it seems, affords no refuge but rather exposes vulnerabilities; it is the source of contention and conflict, the site where rivalries, tensions, and resentments are played out. When the heroine's cast-off suitors seek solace by marrying her close friends and relations (invariably perceived as poor substitutes), the seeds are sown for jealousy and family dissension to erupt again in future years and generations. ${ }^{11}$

In Burney's work, female rivalry infects virtually every family, ${ }^{12}$ in which seemingly friendly relations may be 'capable of much selfishness and duplicity ${ }^{\prime 13}$ where their own self-interest is concerned. In the marriage game where the stakes are high, jealousy lurks beneath the surface of even the closest friendships. The novels create competitive situations by doubling the number of female contenders for marriageable males. Temptation and betrayal are the result. For instance, in Traits of Nature, the flighty Mrs. Erington, 'who, notwithstanding all her flightiness, was by no means divested of attention to her own interest, ${ }^{14}$ has devised a scheme to supplant her half-sister in a wealthy suitor's affections, by pretending to console him in the absence of his favorite.

'Upon my word, if I did not do all in my power to keep up your interest with him, there is some danger that this long absence would entirely dislodge you from his heart. But I talk to him for you - I listen to him for you,...I smile upon 
him for you - and, last night, I even danced with him for you.'

'And some day or other,' said Adela, smiling, 'perhaps, you may marry him for me! $!^{15}$

The tale of Country Neighbours (1820) is unusual in its representation of a supposedly warm-hearted family where a strong-minded mother dominates three harpies, each cherishing pent-up resentments. The resulting portrait was disturbing enough for at least one male reader to protest. ${ }^{16}$ More often, as with the female viper, Jemima Cleveland, the rivalry shades into malice and aggression, insidiously expressed through common forms of civility. Burney's depiction of enmity contained within the domestic circle is typified by one character's description of a family gathering: 'we are all secretly watching each other; all dissatisfied, comfortless, and suspicious. ${ }^{, 17}$

The matriarchal world of Clarentine is unusual; more often in Burney, the movement of the heroine is the psychologically resonant one - away from identification with the mother, towards 'an improved relationship with her father. ${ }^{\prime 18}$ The heroine's acceptance in a patriarchal society usually involves a repudiation of her maternal legacy. This pattern is seen in three of Burney's works in which the feminine trait of weakness, either of character or morals, has led to disgrace or tragedy. In order to win her father's approval and establish her social identity, the daughter must dissociate herself from her mother and reject her past. In a striking scene in Geraldine Fauconberg, the titular heroine confronts her mother's portrait and contemplates her guilt.

I dreaded, yet was most solicitous to hear the particulars of her story: involuntarily, I more than half acquitted her; it was dreadful to me to believe she had designedly wrought such fearful mischief....

The sight of her picture,... - of that innocent countenance, those dovelike eyes, that appeared gently to reproach me for the unfavorable thoughts that sometimes intruded themselves into my mind, - struck me with a sentiment bordering upon remorse. I stood immovable before the silent, yet speaking canvass; large drops of sorrow coursed one another down my cheeks, and I felt them not till they penetrated through my garments, and chilled my bosom. ${ }^{19}$

Yet her mother's downfall has come partly through those virtues for which Geraldine herself is celebrated (her unselfishness, her willingness to please and accommodate others) and which make her peculiarly formed to shine in domestic life. ${ }^{20}$ The mother's pliancy in bending to her father's will leads her to give up a beloved fiancé and accept a splendid match of his own choosing. Her obedience costs her dearly; the 'timid facility' ${ }^{21}$ of her tender nature is blamed for destroying her own 
life and the lives of all the men associated with her. ${ }^{22}$ At the core of the paternal mansion, reflected in the portrait of this paragon of domestic virtues, lie the seeds of emasculation.

In Burney's third novel, Traits of Nature, the movement away from the mother is even more marked - involving adultery and a scandalous divorce. Adela, haunted by the guilt of her mother's infamy, is exposed to insult and calumny, even the suggestion of possible illegitimacy, heightened by her father's refusal to admit her into his dwelling. Her central quest is to win not the hero (whose love is established and reciprocated early on) but the sanction of her father, an unforgiving tyrant. Her return to the paternal household is a muted form of the father-daughter reconciliations which marked so many novels of the period. After she succeeds in winning her father's approval, she hears of her mother's death and sheds a private tear - the only character to do so. ${ }^{23}$ The maternal legacy could hardly be more effectively repudiated.

Country Neighbours offers an interesting variation on this theme. As a young woman, Blanch's mother had captivated the Tourbervilles, father and son, before eloping with the latter. Her fatal attractions have led unwittingly to the death of her impetuous young husband in a duel. The elderly baronet blames her for alienating the affections of his son and heir and undermining the patrilineal succession.

But - to me,... - she has been a scourge too fatal ever to be forgiven! By her was kindled and thrown amongst us, a torch of discord which consumed every tie that bound us to each other. She found us happy - reciprocally attached looked up to by the world with envy - and gratefully conscious of the blessings of our lot. She rendered us...oh, Blanch! how will you bear to know the ruin which she brought upon us! ${ }^{24}$

When he discovers that his nephew's fiancé is the daughter of this femme fatale, he refuses to sanction the marriage or to endow it with the promised munificent settlements.

The reaction of Blanch (whose uncompromising integrity inspired a sonnet penned by Charles Lamb) ${ }^{25}$ is unusual. She refuses to make the transition to her fiancé's family at the price of denying her maternal identity. She staunchly defends her mother's virtue, on which is grounded her own sense of self-worth: 'Never daughter loved - venerated - exulted in a mother as I did - as I still do - in mine.... - I will stake my life upon her unsullied worth and goodness! ${ }^{26}$ Moreover, she steadfastly refuses to marry while the issue of her mother's character is still in doubt, since she will not enter any family which entertains such detrimental prejudices against her. Blanch is indeed a spirited heroine, who attracts the love of the hero by rescuing him from drowning, and 
orders him to seek his mother's sanction before she will listen to his professions. When her mother's reputation is finally vindicated, it is Sir Reginald who takes a carriage to her door and (in an inversion of a father-daughter reunion), begs for forgiveness.

Nevertheless, the final outcome conforms to the pattern of transition from the maternal to the paternal, from the matriarchal Stavordales to the paternalistic Tourbervilles, from whom Blanch's descent is discovered. In leaving her beloved female relatives, she is consoled by the realization that in her husband, she will also be gaining a cousin - that a new set of ties is forming round her. It is the pleasure of kinship and consanguinity, not romantic love, which compensates her for the family she must leave. The formation of a new family as a reaffirmation of the old occurs also in Traits of Nature, where the hero dwells with satisfaction on reinforcement of family ties: 'learn, that your brother is now also become $m y$ brother - that he is the husband of my sister! ${ }^{27}$

There are many couples in Burney who are not so lucky. Scattered throughout her fiction are admonitory examples of love gone wrong: for instance, the abusive Sir Henry Tresilian who, like a soured Mr. Bennet, delights in tormenting and ridiculing his small-minded wife; ${ }^{28}$ or the young Mrs. Everley, chained to an elderly pedant, like 'a captive bird pining for its native groves, its early companions, and its lost liberty. ${ }^{29}$ The depiction of marriage as a trap and the pressure on the individual to conform is seen when families try to influence the choice of mate in order to consolidate family property. Those whose matches are either promoted or forbidden feature in plots and sub-plots. The manoeuvring mother stands out in Burney's final work; soured by the failure of matrimonial projects for her children, she is blamed for the crimes of seduction, murder and suicide which darken the tale. ${ }^{30}$

Marriage is often presented as a confirmation and re-formation of the original family, as Paula Cohen points out in The Daughter's Dilemma. Central to many eighteenth and nineteenth-century novels, the courtship plot functions

less as a transition for the heroine - a means by which she can cross over to something new - than as a source of deferral of that most disruptive event in the life of the nuclear family: the event of leaving home....the novels enact an erotics not of delayed gratification but simply of delay. The plot creates the illusion of a passage to a new life when it really prolongs and elaborates the heroine's life in her family of origin. ${ }^{31}$

In effect, 'the romantic relationship that develops has already been coded as a familial one,' in which a 'sister-heroine' and 'brother-hero' will unite in a 'symbolic reconstitution of a family of origin. ${ }^{32}$ 
The central love interest of Burney's fiction is often based on a fraternal regard. In Clarentine, the titular heroine's grateful affection for Somerset is based on his kindness to her as a child. Similarly, in Traits of Nature, the hero's ardor draws on cherished memories of childhood, and a thorough knowledge of his beloved's disposition. In The Hermitage, Ernest de Gray returns from his travels to rediscover his childhood playmate. Sometimes, a sibling-like connection is established in other ways. In The Shipwreck, shared adversity serves as a formative experience, leading Fitz Aymer to vow his love as 'a faithful and devoted brother! ${ }^{33}$

In Burney's last work, The Renunciation (1839), the interweaving of all these themes can be seen. The romantic love interest, never a strong preoccupation, virtually disappears. ${ }^{34}$ The heroine's urgent need is to find kin, played out against a backdrop of exile on the continent. The sense of loss and displacement is overwhelming, which may be due in part to Burney's circumstances. At the time of writing, she was living in isolation as an expatriate in Italy. ${ }^{35}$ The tale 'presents with convincing subjectivity' (as Isobel Grundy has noted), ${ }^{36}$ the desolation of a homesick child. A young girl is kidnapped and taken abroad by an unscrupulous guardian to impersonate a young heiress. The lonely dejection of little Agnes is rendered vividly: 'I have no parents; the friends who once were so kind to me, seem now to have given me up. I know not in whose power I am - and, except yourself, I have no one to love, no one to trust. ${ }^{, 37}$

Like other Burney heroines, she learns to fear, never to love, her paternal protector; detesting a life of imposture, she escapes, bringing ruin upon his head. She travels across Europe in quest of someone to whom she can belong; 'the favorite wish of her heart - [is] that of finding herself possessed of a brother. ${ }^{\prime 38}$ Instead, she is reunited with a wealthy uncle, aristocratic friends and the heir whose fortune she has been defrauding.

The striking thing about this novel is the way it doubles back upon itself in multiplied motifs of lost or kidnapped heirs, unloved, abused children, and fraudulent guardians, enveloped in clouds of bankruptcy and ruin. The heroine falls in love with the hero upon hearing the sad story of his childhood (which mirrors her own) and sympathizing with his feelings of inadequacy and rejection. ${ }^{39}$ In time, Agnes learns that she already possesses the kin which she so desperately seeks. The stranger who offers his protection is in fact her uncle. Even more coincidentally, the man who kidnapped her off the street proves to be her real father the heiress she has impersonated, that favored half-sister who had eclipsed her so many years before. She has impersonated, if not herself, at least a more favorable construction of her own childhood circumstances. 
The family group at the end is a reconstituted form of her family of origin, renewed, reinvigorated and realigned, so that the kinship ties are truly those of disinterested affection, won by merit and proven by adversity. Wealth is conferred only after the heroine succeeds in earning a living as a portrait-painter (she shows more success in her bid for self-dependence than Frances Burney's protagonist in The Wanderer). Her real father remains firmly in exile; although (she is assured) 'as your father,...he shall always be secured from pecuniary difficulties, ${ }^{40}$ he never returns to disturb this happily reconstructed family group. The tale literally enacts 'the daughter's integration of herself into an original family system that has long been lost to her. ${ }^{41}$

It appears that the family in Sarah Harriet Burney's novels is perfected when expunged of its dominant male head. The development of the incipient patriarch through a pernicious system of education is considered in several works. In the nursery, young boys who show 'little impetuosities of temper ${ }^{\prime 2}$ and assertions of self-will are left unchecked, indulged by the 'unhappy system of favoritism' ${ }^{43}$ which favors the male. Grown to manhood, ${ }^{44}$ these 'rash, petulant, headstrong' ${ }^{45}$ characters wreak havoc in society through habits of willful self-indulgence. As fathers, they become 'irascible, haughty, tyrannical ${ }^{46}$ and in old age, their intransigence leads to an abuse of power. ${ }^{47}$ In the work of Sarah Harriet Burney it is male, rather than female education, which is a subject of interest; the feminine character, inured early on to self-control and self-abnegation, offers a positive counterbalance to masculine characteristics. ${ }^{48}$

It seems that Burney's solution to the emotional distress and oppression of patriarchy is solved in increasingly violent ways - by repudiating the male principle. In her last work of fiction, the unlovable father of The Renunciation is exiled to America, and the impetuous brother in The Hermitage, whose callous self-indulgence leads to tragedy, is brutally murdered. Her last published work brings to culmination the sense of unease which runs through her fiction. Focusing on the family in the fiction of Sarah Harriet Burney reveals the darkness and complexity which lie at the heart of her representations of the domestic circle.

LORNA J. CLARK 


\section{Notes}

1 Sarah Harriet Burney, Traits of Nature (London: Henry Colburn, 1812), 3:224.

2 Useful works on the family in this period are Mary Abbott, Family Ties: English Families 1540-1920 (London and New York: Routledge, 1990); Linda A. Pollock, Forgotten Children: Parent-Child Relations from 1500 to 1900 (Cambridge: Cambridge University Press, 1983); Randolph Trumbach, The Rise of the Egalitarian Family: Aristocratic Kinship and Domestic Relations in Eighteenth-Century England (New York: Academic Press, 1978); Bridget Hill, Eighteenth Century Women: An Anthology (London: George Allen \& Unwin, 1984); and G. Barker Benfield, The Culture of Sensibility: Sex and Society in Eighteenth-Century Britain (Chicago: University of Chicago Press, 1992).

3 Nathan W. Ackerman, The Psychodynamics of Family Life: Diagnoses and Treatment of Family Relationships (New York: Basic Books, 1958), 112.

4 Nancy K. Miller, The Heroine's Text: Readings in the French and English Novel, 1722-1782 (New York: Columbia University Press, 1980), 4.

5 Burney, Traits, 4:173.

6 Sarah Harriet Burney, Tales of Fancy (London: Henry Colburn, 1816-20), vol. 1, The Shipwreck, 209.

7 Sarah Harriet Burney, The Romance of Private Life (London: Henry Colburn, 1839), vols. 1 and 2, The Renunciation, 2:184.

8 [Sarah Harriet Burney], Geraldine Fauconberg (London: G. Wilkie and J. Robinson, 1808), 2:40.

9 Miller, 5.

10 [Sarah Harriet Burney], Clarentine (London: G. G. and J. Robinson, 1796), 3:159.

11 Clarentine's impassioned cousin, Sir Edgar Delmington, slowly and painfully reconciles himself to the necessity of honoring his engagement to her best friend, Lady Julia Leyburne. Meeting Clarentine by chance overturns all his good resolutions and dispels any belief in his newly acquired indifference. Clarentine's importunate suitor, Mr. Eltham, later proposes to her cousin Sophia with some reservations: 'I will not tell you that I feel for you that extravagant and impetuous passion I felt for your fascinating cousin'; however, he informs her that her more moderate attractions of character and countenance have 'half turned my head!' (3:168).

12 E.g. A typical example is the subplot of Traits of Nature in which William Hampden has eloped with a well-born bride. The young couple's efforts to seek forgiveness are foiled by the duplicity of a sister-in-law who claims to sympathize with them, but meanwhile destroys their letters to the bride's father.

13 Burney, Traits, 5:14.

14 Ibid., 4:44-45.

15 Ibid., 126.

16 Henry Crabb Robinson, a well-disposed reader and friend of Burney, was taken aback by her material. He first reported, on 12 December 1831, 'The greater part of the day was devoted to reading my friend Miss Burney's "Country Neighbours" which I am trying to relish' but by the next day, his tune had 
changed: 'I finished "Country Neighbours" today - I shall hardly venture on another novel by Miss B: - the characters are feeble except that of the mother and she is a shrew. It would have been better had the supposed author not been a daughter and sister and aunt by which a heartless character is given to her reflexions' (Henry Crabb Robinson, 12, 14 December 1831, Diary, Dr. Williams's Library, London).

17 [Burney], Geraldine Fauconberg, 3:258-9.

18 Paula Marantz Cohen, The Daughter's Dilemma: Family Process and the Nineteenth-Century Domestic Novel (Ann Arbor: University of Michigan Press, 1992), 26.

19 [Burney], Geraldine Fauconberg, 3:274-5.

20 'From infancy, her great merit has been the singular and total exemption from every species of selfishness which has invariably marked her character. There is no sacrifice she would not make to friendship or to duty:...She feels, but she never repines; she is benevolent, but she never parades. Simple in her manners, ingenuous and affectionate, she seems to understand, in its highest perfection, the rare and happy art of diffusing contentment and cheerfulness throughout a domestic circle.' ([Burney], Geraldine Fauconberg, 1:4)

21 Ibid., 3:297.

22 The melancholy tale is told in [Burney], Geraldine Fauconberg, 2: 222-5 and 3:296-8.

23 'Adela alone, of all who had ever known her, shed a tear to her memory, and lamented her premature fate.' (Burney, Traits, 5:246)

24 Sarah Harriet Burney, Tales of Fancy (London: Henry Colburn, 1816-20), vols. 2 and 3, Country Neighbours, 3:184.

25 Charles Lamb, 'Sonnet, To Miss Burney, on her Character of Blanch in "Country Neighbours," a Tale,' which first appeared in the Morning Chronicle, 13 July 1820, is reprinted in The Works of Charles and Mary Lamb, ed. E. V. Lucas (London, 1903; reprint, New York: AMS Press, 1989), 5:82-83.

26 Burney, Country Neighbours, 3:179, 183.

27 Burney, Traits, 5:213.

28 See, e.g. [Burney], Geraldine Fauconberg, 2:8-25.

29 Ibid., 1:98.

30 Sarah Harriet Burney, The Romance of Private Life (London: Henry Colburn, 1839), vol. 3, The Hermitage.

31 Cohen, 26.

32 Ibid., 26, 28.

33 Burney, Shipwreck, 1:197.

34 Sarah Harriet Burney remarked unequivocally in 1811, 'Novel Romance makes me puke!' and later in 1816 confessed: 'I never insert love but to oblige my readers: if I could give them humour and wit, however, I should make bold to skip the love, and think them well off into the bargain. But writing for the press,...cramps my genius, \& makes me weigh my words, and write as you call it mawning,' The Letters of Sarah Harriet Burney, ed. Lorna J. Clark (Athens, Georgia: Georgia University Press, 1997), 125, 201. 
35 For a description of her increasingly isolated existence in Florence, see Letters, li-liii.

36 Isobel Grundy, 'Sarah Harriet Burney,' The Feminist Companion to Literature in English: Women Writers from the Middle Ages to the Present (London: B. T. Batsford, 1990).

37 Burney, Renunciation, 1:53.

38 Ibid., 2:174.

39 A close friend of Walsingham reports, 'The fact is, his mother's inexplicable coldness and neglect, affected him deeply even from his boyhood; and I remember to have heard him more than once assert, that it was to be feared the man who possessed not the qualities that could endear him to his own mother, was born to pass through life unloved by any other woman!...Agnes' affection has totally dispelled all this melancholy distrust, and such is the effect upon him of the confidence he reposes in her, that he no longer appears the same man;... he has gained infinitely by the change.' (Burney, Renunciation, 2:306-7)

40 Ibid., 246.

41 Cohen, 29.

42 Burney, Traits, 3:194. There are two young tyrants in the nursery in this novel, Julius Cleveland and five-year-old Ossely Mordington.

43 Ibid., 301.

44 As well as the youth Julius Cleveland in Traits of Nature, Frederic Ormond in The Hermitage and even Ferdinand Lesmore in Geraldine Fauconberg are, to some degree, examples of this type.

45 Burney, Traits, 5:23.

46 In Traits of Nature, Mr. Cleveland and Mr. Earlingford both fit this description.

47 E.g. Sir Reginald Tourberville in Country Neighbours.

48 An interesting exploration of related topics is in The Significance of Sibling Relationships in Literature, ed. JoAnna Stephens Mink and Janet Doubler Ward (Bowling Green, Ohio: Bowling Green State University Popular Press, 1990). Particularly useful essays in this work are Elisabeth Rose Gruner, "Loving Difference": Sisters and Brothers from Frances Burney to Emily Bronte,' 32-44, and Julia Waddell, 'Women Writers as Little Sisters in Victorian Society: The Mill on the Floss and the Case of George Eliot,' 47-109. 